\title{
Dependence of the Knowledge Structure of the Company Employees on a Set of the Competencies
}

\author{
Natalia Yevtushenko*,1, Nataliia Kuzminska², Tetiana Kovalova ${ }^{3}$ \\ ${ }^{1}$ Institute of Management and Entrepreneurship, State University of Telecommunications, Kyiv, 03110, Ukraine \\ ${ }^{2}$ Faculty of Management and Marketing, Igor Sikorsky Kyiv Polytechnic Institute, Kyiv, 03056, Ukraine \\ ${ }^{3}$ Faculty of Management and Business, Kharkov National Automobile and Highway University, Kharkiv, 61002, Ukraine
}

\begin{tabular}{l} 
A R T I C L E I N F O \\
Article history: \\
Received: 26 December, \\
Accepted: 09 March, 202 \\
Online: 20 March, 2021 \\
\hline Keywords: \\
Management \\
Consulting \\
Competencies \\
Competitive advantages \\
Intellectual resource \\
Knowledge and skills \\
Model
\end{tabular}

\section{Introduction}

The main characteristic of modernity is the rapid development of the processes functioning in it, which requires the employees of the enterprise to quickly adapt to the environment. The changes that occur in connection with the integration of capitals affect the transformation of relationships both within the enterprise and outside it. Updated technologies or made new products innovation (services) provide an enterprise with only short-term advantages, since competitors quickly adopt innovations, which allows them to occupy a leading position in the market.

${ }^{*}$ Corresponding Author: Natalia Yevtushenko, evtushenko.13.nat@gmail.com www.astesj.com

https://dx.doi.org/10.25046/aj060281

\begin{abstract}
A B S T R A C T
The article substantiates the relevance of conducting research on the structural characteristics of a company's employee knowledge, which is the result of his mental activity and his practical experience. The conditions under which information becomes a source of employee knowledge are determined. An abstract analysis of the process of transforming knowledge into an intellectual product - the competence of company employees is presented. In the process of the comparative analysis of the concept of «competence» its dual content is substantiated. Taking into account the recommendations of the scientific and methodological approach to building the model «Effective Consultant», its practical implementation was carried out on the example of the activities of consultants of a consulting company, taking into account the levels of their development and their performance of professional tasks. The article clarifies the essence of the concepts "consultant-manager» and "consultant-expert», describes the main stages of implementation of the model "Effective consultant» of the company. Calculations were carried out to assess competencies, which were previously divided according to group characteristics (superficial general and special, behavioral, adaptive and personal). Based on the results of the assessment, a set of key competencies of consultants was formed in the form of a package "Intellectual resource». Based on the results of the study of the dependence of the knowledge structure of the company's employees on their competencies, the practical rationality of the application of the scientific and methodological approach to the formation of the "Effective Consultant» model has been brought. The practical significance of the calculations performed using the method of expert assessments - hierarchy and priorities has been established. It has been substantiated that such an approach will allow companies to effectively use the intellectual knowledge of employees as a stable competitive advantage, and in the shortest possible time to achieve a high economic effect.
\end{abstract}

The knowledge and skills of employees who are able to effectively use the limited resources of business entities form a special influence on the processes of maintaining competitive advantages. An employee of any company, who has a high level of general education, scientific and professional training, is capable not only of reproducing the acquired knowledge, but also of generalizing, analyzing and generating new knowledge in accordance with the needs of the labor market and operating conditions.

An important role in these processes is assigned to information resources, which, along with labor, capital and natural resources, 
determine the efficiency of production and the logic of macroeconomic dynamics. And, unlike the recent past, when the statement of the English banker, businessman, financier Nothan Rothschild was relevant that who owns information, he owns the world for the present, it is important, if not the generation of information, then at least the ability to quickly analyze and transform it into intelligent products. In these conditions, there is a process of formation of special professional characteristics of employees - competencies, which eventually determine the competitive advantages of the enterprise.

\section{Literature Review}

Well-known foreign and domestic scientists made a great contribution to the formulation and theoretical development of issues that illuminate the content of the concept of "competence" and the conditions for the formation of a set of competencies for employees of enterprises, depending on the knowledge gained on the basis of the resource concept.

In the course of their research, in [1], the famous Ukrainian scientists emphasized knowledge, which is becoming a major factor in the post-industrial economy, and efficiency, which is not being paid enough attention to. They support the research of Swiss scientists, where only $20 \%$ of the knowledge possessed by the company's employees finds real application, despite the fact that $42 \%$ of corporate knowledge is the intelligence of the personnel, which is not recorded in any way on physical media.

Most often, knowledge is associated with such a concept as competence. For the first time the concept of "competence" was proposed by the American psychologist D. McClelland, who in 1973 in his article "Measuring competence instead of measuring intelligence" noted that competence is necessary to predict the level of performance of efficiency According to his interpretation, competence is a circle of problems or a field of activity in which a person has knowledge and experience. In his theoretical study, [2] author described enterprise competence as a set of personnel competencies. The studies that conducted showed that traditional academic tests of aptitude and knowledge, as well as the availability of any diplomas from potential job performers, do not provide them with the effectiveness of performance of work duties and success in professional activities. Such conclusions led to the search for "competencies" as characteristics that distinguish and predict the level of performance of efficiency in specific performers.

In [3], the authors are considered directly the developers of the competence-based approach, according to which competence is the basic quality of an individual, which has a causal relationship to effective performance in work or other situations. Basic quality means that competence is a permanent (persistent) part of the personality that can determine a person's behavior in a large number of situations and work tasks.

In [4], well-known scientists proposed the concept of key competencies, they became the founders of the work «Key competencies of corporations» (1990), which continued the development of the competence approach. These scholars define core competencies as the skills and abilities that enable a company to deliver fundamental benefits to consumers. Proposing their concept, in [5], the authors argue that the term "core competence" is used to characterize a set of skills and technologies, a set of unsystematically accumulated knowledge and experience by a company, which become the basis of successful competition.

In [6], the authors note that almost every company has at least one type of activity in which it has succeeded enough to consider the knowledge gained there as key competencies, that is, one that provides a competitive advantage. They argues that key competencies do not have a direct impact on the success or failure of a brand, since they are not directly focused on the needs of consumers and therefore cannot contribute to consolidating the brand's position. Excellence in the marketplace can be achieved not simply through unique enterprise resources and capabilities, but through their proper application.

A number of scientists distinguish between "knowledge" and "value" components in the competence. Thus, European scientists in the TUNING project note that the concept of competence includes knowledge as understanding (theoretical knowledge of the academic field, the ability to know and understand), knowledge of how to act (practical and operational application of knowledge to specific situations), knowledge of how to be (values as inherent part of the way of perception and life with others in a social context) [7]. In [8], the the authors explains that competence is a general ability based on knowledge, experience, values, inclinations that are acquired through training. In [9], the authtor described the term "competence" as the ability to solve problems, provided not only by the possession of ready-made information, but also by the intensive participation of the mind, experience, and creative abilities of students.

In [10], according to the views scientists competence is considered as an open system of procedural, value-semantic and declarative knowledge, taking into account the interacting components (associated with cognition, personal, social), which are activated and enriched in activity as real vital problems arise that the bearer of competence faces. In this sense, in [11], the autor notes that competence is a set of interrelated personality traits (knowledge, abilities, skills, means of activity), which are set relative to a certain range of objects and processes, as well as necessary for effective productive activity.

However, the development of a rational and effective set of competencies for employees of the enterprise in accordance with the structure of knowledge that they received during their professional activities based on the model of an "effective consultant" of the company remains outside the field of vision of most scientists on personnel management..

\section{Methodology}

\subsection{Studies of the structural characteristics of knowledge as an economic category}

All the arguments that are accepted and form the human worldview are not uniquely determined by the data of experience, but depend on the choice of the conceptual apparatus with which they can be interpreted. At the same time, choosing one or another conceptual apparatus, one can change the entire worldview. The main thesis of traditional conventionalism, of which, for example, A. Poincare is a representative, is that there are problems that cannot be solved based on experience until some conventions 
(concepts) are introduced, and only then these conventions together with experience data allow you to solve the problem. Therefore, before proceeding to highlight the objectives of the article, it is appropriate to provide an understanding of the basic concepts.

In the scientific literature, you can find many approaches to the problem of the relationship between the concepts of "information" and "knowledge". Some scientists identify these concepts, consider them interchangeable. So, for example, the concept of "information" [12] as a set of knowledge, images, feelings available in the mind of a person or artificial intelligence, coming through various transmission channels, are processed and used in the process of human life and the operation of automatic computer systems, and the concept of "knowledge" [13]: information available in the mind of a person serves to solve intellectual and speech problems, is used in everyday cognitive and speech activities, predetermines human behavior.

In [14], scientists notes that knowledge today is information that has practical value: arise from the need to achieve effectiveness. If knowledge isn't challenged to grow, it disappears fast.

In [15], the authors call knowledge the information contained in the human mind and is used to make decisions in a situation of uncertainty. In the sense of this study, as in cognitive psychology, the concepts of "information" and "knowledge" are clearly differentiated: knowledge is formed from information by means of its transformation and transformation, knowledge is an ordered accumulation of information. Based on this, objectivity is inherent in information, and knowledge is influenced by individual or social subjectivity.

In [16], the author described that sensory knowledge (information) is somewhat changeable, single, and knowledge is constant, stable, general, knowledge is nothing without understanding. The conditional structure of human knowledge can be depicted as a chain (fig. 1).

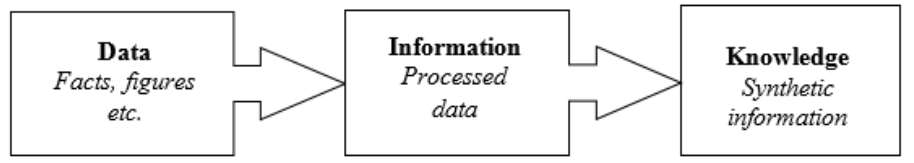

Figure 1: Conditional structure of knowledge

Data is a collection of facts, numbers (for example, measurements), in general, it is raw information. After processing the content data, information is obtained through analysis. As a result, of the synthesis of information, more complex structures are formed based on models describing an object or process, and knowledge arises. People, groups of people collect, process information and form knowledge. Knowledge is the result of a person's mental activity, his professional experience gained as a result of practical activity, or, in other words, information becomes knowledge when it is realized by a person, becomes part of her surrounding world, affects her opinion and actions. So, a specialist in a certain field is someone who is able to carry out the process of transforming data information knowledge.

Regarding the concept of "knowledge", there are many theories about their classification, but the most common is the division into "explicit" (objective, with a clearly expressed content, which can be written down, saved, transmitted, disseminated) and "hidden" (abstract, non-formalized, most often, subjective sensory knowledge, which is based on individual experience, represent beliefs, ideas). In the scientific literature, you can find similar names: "wandering" and "attached", formalized and non-formalized, "hard" and «soft" and others.

Based on this distribution, in [17], the author described the theory of knowledge creation ("SECI model"). He believes that the creation of knowledge is an abstract spiral process of interaction between explicit and hidden knowledge, which leads to the emergence of new knowledge. This knowledge transformation process is shown in Figure 2. The transformation of knowledge, which is carried out by a successive transition through four processes, forms a spiral, so that it increases with each new turn of the spiral both in the vertical and in the horizontal plane, embracing the new knowledge of people. Space in which the spiral located, I. Nonaka called "Wa" (from Japanese philosophy - the space in which the created knowledge is located), and the knowledge that accumulates as a result of the model's action is "activated" knowledge. "Wa" is divided into four types depending on sequential processes: postal (environment for socialization), conversational (for externalization), simple systemic (for combination), research (for internationalization). These types correspond to different levels of knowledge.

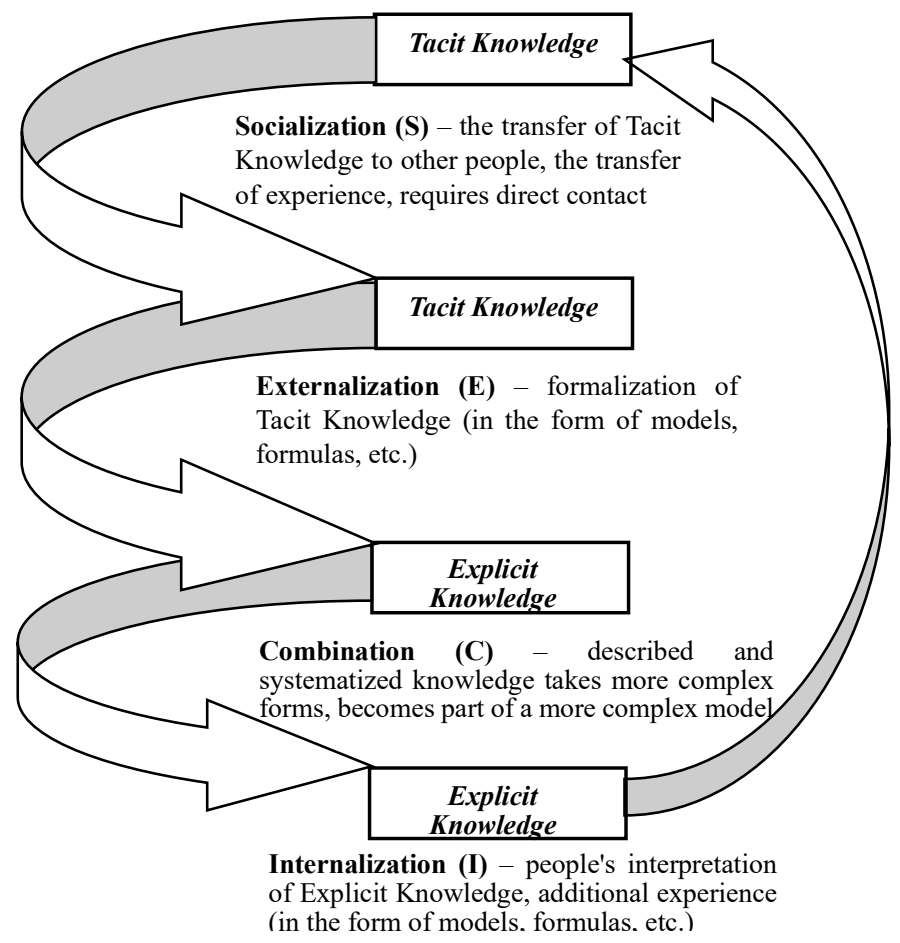

Figure 2: The SECI model

It should be noted that according to I. Nonaka's theory of knowledge creation, knowledge cannot be created from nothing. To create them, you need resources - "assets" of knowledge, which are the source for creating knowledge. "Assets" are divided, according to the previously considered processes (fig. 2) and types of "Wa", into: empirical (transmitted exclusively through the exchange of experience), conceptual (transmitted through images, symbols, language), template (laid down in practical activity based 
on internal rules and operating conditions of the enterprise) and systemic (formalized knowledge such as patents, copyright certificates, regulatory documents, etc.). Such distribution, according to I. Nonaka, will allow the company to take into account the "assets" of knowledge more effectively.

Nowadays, knowledge of the company (practical knowledge, experience of employees, patents, etc.) is an important and rather valuable resource or "intangible asset". Usually, the process of preserving knowledge, one way or another, is implemented in each company, since reports, instructions, notes and other documents are created. Over the years, the number of documents only grows, then no one at all remembers about some of them and does not use them. This leads to ineffective use of the "assets" of knowledge of the enterprise [18]. In such circumstances, the company's employees become the main resource that is able to rationally use their knowledge and apply it effectively, depending on tactical and strategic situations in the process of the company's functioning.

\subsection{Analysis of the process of transforming knowledge into an intellectual product - competence}

In [19] and [20], prominent scientists noted that the employee, as human capital, was defined as the main resource that, depending on the circumstances, uses a set of his knowledge, skills and abilities to effectively manage the resources of the enterprise, and forms the competitive advantages of the company, characteristic and significant features of its products and market behavior, its know-how, image and brand. From the standpoint of the competence-based approach proposed, the employee's set of knowledge should be considered as the competitive advantages of human capital in accordance with the formed set of key competencies.

Studies prove that in the scientific world there is no clear opinion on the concepts of "competence". So, according to the personal approach (American School), competence is the highest level of achievement of knowledge, which is considered as a quality (characteristics, ability) of a person, ensuring success in work. Supporters of the functional approach (British School) prove, competencies are the structural components of general competence, which are understood as the characteristics of work tasks and expected results of work. Most scientists perceive the personal aspect of the American School in addition to the functional aspect of the British School, since it provides criteria for the level of development of workers, studies positions, performance standards, professional requirements, while the American aspect studies the employee, his abilities and qualities [21]. The results of research by scientists confirm the fact that competence is the ability of a person to effectively perform a certain (in particular professional) activity, and competencies (plural of "competence") are personal characteristics of a person that determine his behavior and affect the level of performance of a certain (in particular professional) activities.

Composite analysis of the essence of the concept of "competence" has revealed the dual nature of its substantive characteristics. In this regard, it is proposed to take the definition as the basis for the concept of "competence", where competence is considered as an open system of knowledge, abilities and personality traits, in the process of creating company values, it provides effective productive activity, which is regulated by the professional requirements of the position and quality standards [21]. The complex of competencies of the company's employees creates its intellectual capital, the set of qualities of which is proposed to be divided into [22]:

- -hereditary (features of the nervous system that determine the nature, inclinations of work, thinking, speech, mental inclinations and abilities);

- physical (endurance; agility);

- intellectual;

- convergent abilities (efficiency of the information processing process, first of all, the correctness and speed of finding the only possible (normative) solution in accordance with the requirements of a given situation);

- divergent abilities (creativity - originality, sensitivity to unusual details and metaphorical thinking) ability to learn; cognitive style).

The qualities of human capital are determined, they are individual and specific for each individual employee of the company, they are formed and implemented in the production process through a set of key competencies that the employee improves over time. In these conditions, employees become a strategic resource of the company, and the process of generating and transforming their knowledge will be provided with a set of key competencies in accordance with the standards, norms and rules that are formed in the company.

Using the example of a consulting company in accordance with the existing competence-based approach and taking into account the methodological foundations of the "Effective Consultant" model, the process of formation of knowledge and key competencies of consultants in the mechanism of consulting interaction is first schematically presented (fig. 3) [21].

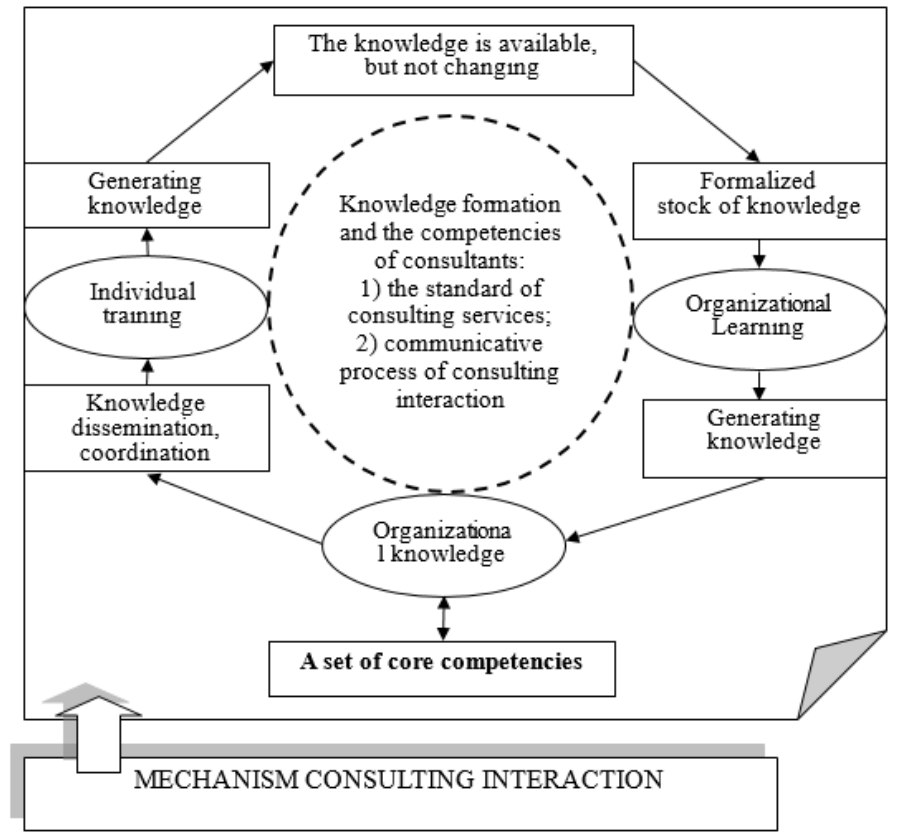

Figure 3: The process forming the knowledge and key competencies of consultants in the mechanism of consulting interaction 
At the beginning we will rank the main features of the concepts "consultant-manager", and "consultant-expert", then will describe the main stages of the implementation of the algorithm of the model "effective consultant" of a consulting company, based on which it is proposed to conduct a practical assessment of the proposed competencies by the levels of performance of their professional tasks.

A consulting company, like any company, has a large intellectual capital (potential) to create its value, the basis of which is the concept of knowledge (value) and information management, which makes it possible to introduce intellectual products into the activities of customer enterprises and give recommendations on their development in a constant competitive struggle and selforganization of their human capital. In their activities, competence is defined as an open system of knowledge, abilities and personality traits; in the process of creating company values, it ensures effective productive activity, which is regulated by the professional requirements of the position and quality standards. The complex of competencies of the company's employees creates its intellectual capital or potential during the communication process in the mechanism of consulting interaction [23].

In the course of the study, the main representatives of the consulting company identified the following groups of consultants as managers and experts. In terms of content, a "consultantmanager" is a specialist who is endowed with the functions of a leader in managing a business and its individual business processes based on a goal-setting system in a strategic perspective, and a "consultant-expert" is a professional in a separate business process who is endowed with qualities of synthesis and analysis, rational assessment of the situation, aimed at achieving the goals set by the manager. The consultant-specialist is the direct executor of the tasks provided by the consultant-manager [21].

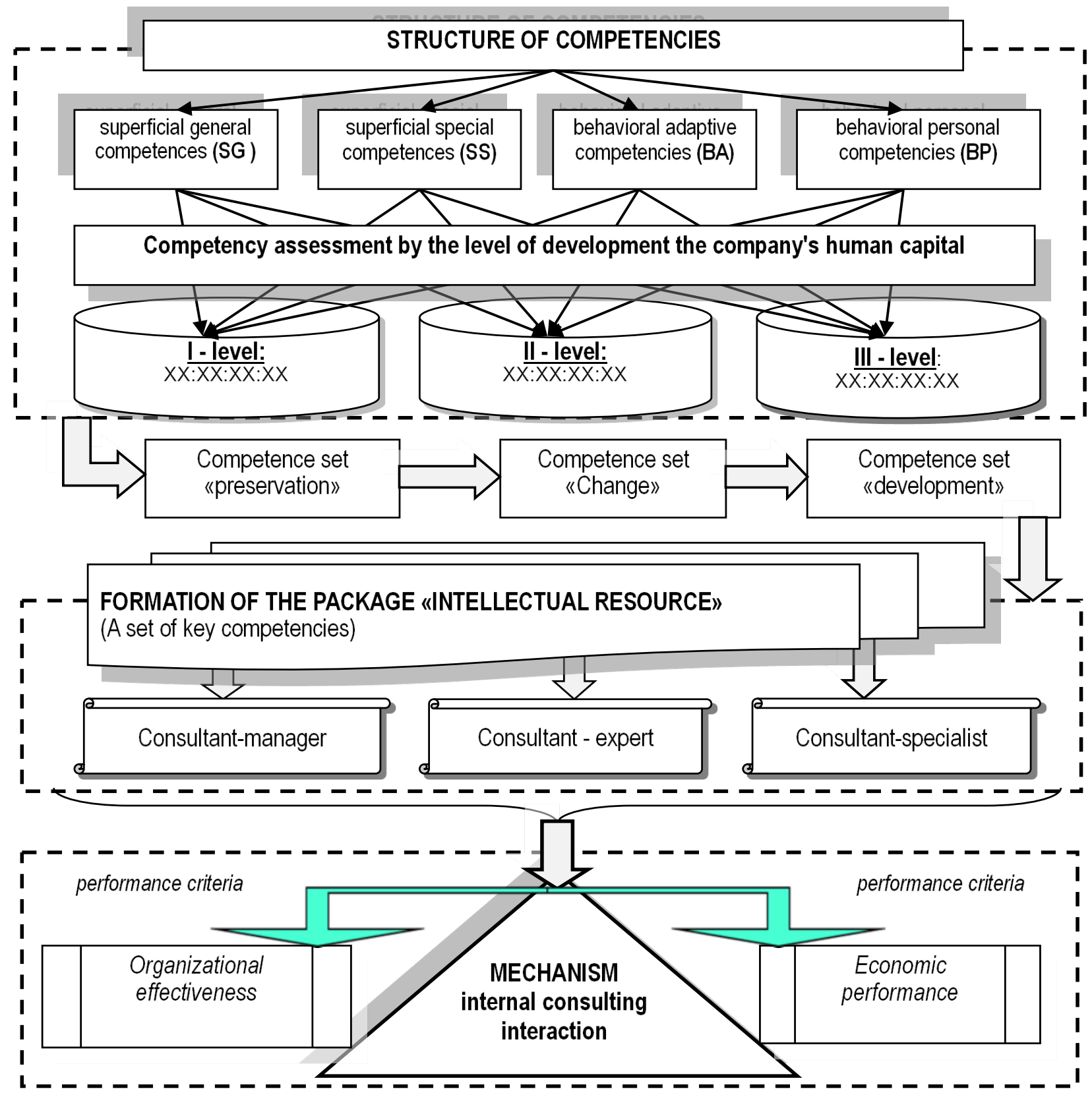

Figure 4: Model "Effective Consultant" of a consulting company as a component of the mechanism of internal consulting interaction 
In the course of its activity, the efficiency of the consulting company is associated with the accurate fulfillment of tasks, in the future, they will affect the quality, content and terms of work performed. The solution of these tasks is proposed to be carried out using methodological tools, which are implemented in the "Effective Consultant" model of a consulting company based on a competency-based approach (fig. 4) [21].

The scientific and methodological approach to the construction the model "Effective Consultant" a consulting company is presented by the author in [21], consists of the following stages:

Stage 1 - the formation of a set of competencies for the company's consultants by levels of human capital development.

At the first stage of the "Effective Consultant" model, we form a set of competencies according to the levels of human capital development (fig. 5), according to which competencies will be considered as an integral indicator, presented in the form of functional dependence:

$$
\mathrm{K}=\mathrm{F}(\mathrm{SG} 1, \mathrm{SS} 2, \mathrm{BA} 3, \mathrm{BP} 4),
$$

where: $\mathrm{SG}$ - superficial general competences,

SS - superficial special competences,

BA - behavioral adaptive competencies,

BP - behavioral personal competencies.

The levels of human capital development of the consulting company are given in (fig. 5) [21].

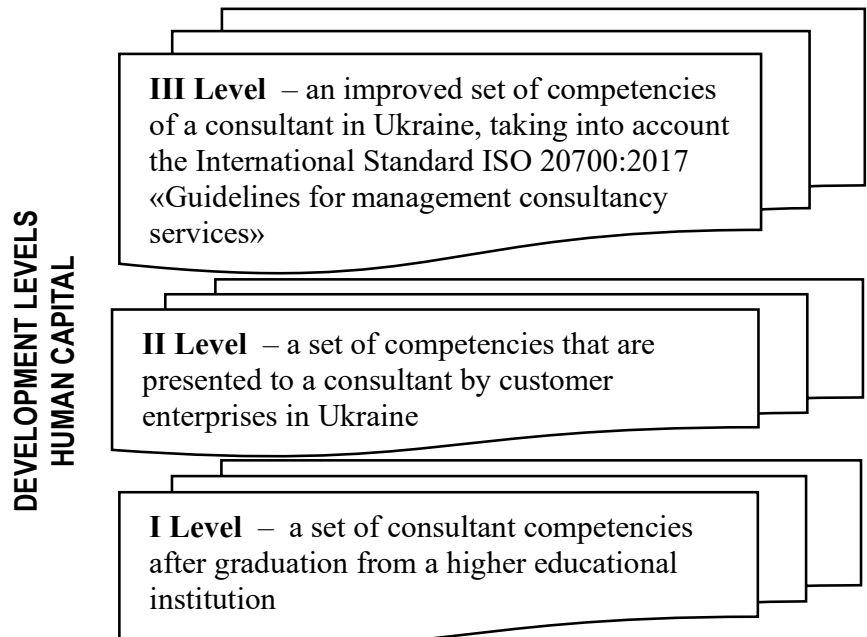

Figure 5: The level of human capital development of a consulting company

Note that the basic set of competencies of a consultant, according to the first level of human capital development, which he receives after graduating from a higher educational institution, are those that are formed in accordance with the guidelines for the development of educational programs [24].

Stage 2. At the second stage of building the "Effective Consultant" model of a consulting company, a set of competencies is assessed by levels of development in accordance with their weight. To determine the degree of production and consumer novelty, the Analytic Hierarchy Process method (AHP) [17] is used. The weight of the factors according to all experts is calculated by the formula:

$$
W_{j}=\frac{\sum_{i=1}^{m} W_{i j}}{\sum_{i=1}^{m} \sum_{i=1}^{n} W_{i j}}
$$

where: $W_{\mathrm{ij}}-$ weight assessment $\mathrm{i}$-th competence given by the $\mathrm{j}$-th expert, score;

$\mathrm{m}$ - number of experts;

$\mathrm{n}$ - number of competencies in the group.

Stage 3. At the third stage, a package of intellectual resource "Effective Consultant" of a consulting company for consultants (managers, experts and specialists) is formed, in which key competencies are selected in accordance with modern requirements.

\section{Empirical findings}

Using the example of a consulting company in Ukraine, we carried out the practical implementation of the stages of building the "Effective Consultant" model.

According to the results of data processing carried out in the process of analyzing the set of matrices for comparison of the Ilevel of human capital development of the consulting company "Competence of a consultant upon graduation from a higher educational institution", the most significant competencies were identified in the groups «Superficial general competences" $(0,644)$ and "superficial special competences $(0,229)$. The key competencies are those that affect after receiving a diploma in the relevant specialty: skills in the use of information and communication technologies; expert knowledge in a certain area (economics, finance, accounting, reengineering, psychology, etc., the ability to generate new ideas, skills to establish interaction with partners (Table 1) [21].

Table 1: The results of the assessment of competencies for the I-level of development - "Competence upon graduation from a higher educational

\begin{tabular}{|c|c|c|c|}
\hline 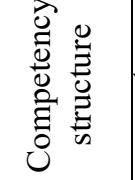 & Weight & $\begin{array}{l}\text { General Competence } \\
\text { (factors) }\end{array}$ & $\begin{array}{l}\text { Weight by } \\
\text { individual } \\
\text { factor }\end{array}$ \\
\hline \multirow{4}{*}{ 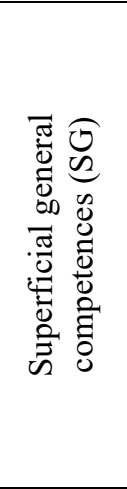 } & \multirow{4}{*}{0,644} & $\begin{array}{l}\text { Basic general knowledge } \\
\text { (higher education for I, II } \\
\text { and III levels) }\left(\mathrm{SG}_{1}\right)\end{array}$ & 0,41 \\
\hline & & $\begin{array}{l}\text { Skills in the use of } \\
\text { information } \\
\text { communication technologies } \\
\left(\mathrm{SG}_{3}\right)\end{array}$ & 0,127 \\
\hline & & $\begin{array}{l}\text { Ability to communicate in } \\
\text { the state and foreign } \\
\text { languages }\left(\mathrm{BP}_{6}\right)\end{array}$ & 0,112 \\
\hline & & $\begin{array}{l}\text { Ability to work with the } \\
\text { regulatory framework }\left(\mathrm{SG}_{7}\right)\end{array}$ & 0,139 \\
\hline \multirow[t]{2}{*}{ 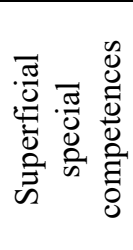 } & \multirow[t]{2}{*}{0,229} & $\begin{array}{l}\text { Expert knowledge in a } \\
\text { specific area (economics, } \\
\text { finance, } \\
\text { reengineering, accounting, } \\
\text { etc.) }\left(\mathrm{SS}_{1}\right)\end{array}$ & 0,325 \\
\hline & & Partnership Skills $\left(\mathrm{SS}_{5}\right)$ & 0,151 \\
\hline
\end{tabular}
institution" 


\begin{tabular}{|c|c|c|c|}
\hline & & $\begin{array}{l}\text { Ability to conclude deals, } \\
\text { establish contacts, negotiate } \\
\left(\mathrm{SS}_{7}\right)\end{array}$ & 0,108 \\
\hline \multirow{3}{*}{ 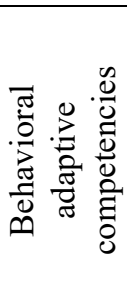 } & \multirow{3}{*}{0,083} & $\begin{array}{l}\text { Research Skills and Abilities } \\
\left(\mathrm{BA}_{1}\right)\end{array}$ & 0,365 \\
\hline & & $\begin{array}{l}\text { Ability to generate new ideas } \\
\text { (creativity) }\left(\mathrm{BA}_{4}\right)\end{array}$ & 0,184 \\
\hline & & $\begin{array}{lll}\text { Ability } & \text { to } & \text { work } \\
\text { independently }\left(\mathrm{BA}_{5}\right) & \end{array}$ & 0,222 \\
\hline \multirow{4}{*}{ 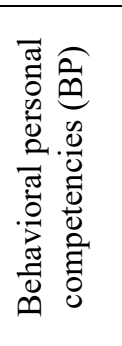 } & \multirow{4}{*}{0,044} & Initiative $\left(\mathrm{BP}_{9}\right)$ & 0,105 \\
\hline & & $\begin{array}{l}\text { Ability for criticism and self- } \\
\text { criticism }\left(\mathrm{BP}_{10}\right)\end{array}$ & 0,143 \\
\hline & & Self-confidence $\left(\mathrm{BP}_{11}\right)$ & 0,108 \\
\hline & & $\begin{array}{l}\text { Desire to achieve success and } \\
\text { provide inspiration to the } \\
\text { team }\left(\mathrm{BP}_{9}\right)\end{array}$ & 0,184 \\
\hline
\end{tabular}

According to the results of processing by experts of the data carried out in the process of analyzing the set of comparison matrices of the II-level of human capital development of the consulting company «Competences that are presented to the consultant by employers in Ukraine», the most significant competencies are determined by groups «Behavioral adaptive competencies» $(0,598)$ and "Behavioral personality competencies" $(0,259)$. Significant are those competencies that are defined as key from the point of view of employers: knowledge of marketing technologies (customer orientation); knowledge of planning changes and developing new projects; interaction risk and conflict management skills; ability to plan and control business processes; skills of making informed decisions (tab. 2) [21].

Also, by rejecting practical tips, which are valued by employer, from theoretical and scientific knowledge, as it is hoped for the completion of study at universities, to form the protagonist of a consulting company as which is becoming a human capital of Ukrainian company.

If we add to the proposed II-level human capital development "Competences that are presented to a consultant by employers in Ukraine" the competence of the International Standard "Guidelines for management consultancy services" in accordance with the International Framework of Competence developed under the leadership of the International Council of Management Consulting Institutions, then we get an improved III-level of development of the company's human capital with "A set of consultant competencies in Ukraine, taking into account the International Standard ISO 20700: 2017".

In the process of improving the set of key competencies at the III-level of human capital development, it was proved that the main ones in the structure of competencies are "Behavioral personal competencies" $(0,658)$ and "Superficial special competencies" $(0,215)$. Significant are the competencies that are separated by key ones taking into account the International Standard ISO 20700:2017:

- skills of risk management of interaction, including risk identification and the ability to work to minimize it;
- ability to observe ethical behavior;

- ability to define success criteria to ensure the required quality of results;

- knowledge of marketing technologies;

- ability to solve problem situations and create innovative solutions for customers;

- $\quad$ skills to form expert opinions;

- to ensure the quality of work performed (projects) and decisions, taking into account the rules and regulations of corporate culture;

- be able to effectively manage their own time to complete tasks on time;

- ability to deepen knowledge and improve skills, based on the experience of their own and other past project tasks;

- skills to analyze the market of consulting services, its competitors and identify the capabilities of a consulting company.

Table 2: The results of the assessment of competencies for the II-level of development - "Competencies that are presented to the consultant by employers in Ukraine"

\begin{tabular}{|c|c|c|c|}
\hline 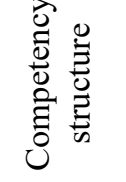 & Weight & General Competence (factors) & $\begin{array}{l}\text { Weight by } \\
\text { individual } \\
\text { factor }\end{array}$ \\
\hline \multirow{4}{*}{ 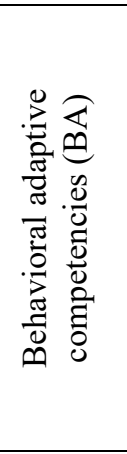 } & \multirow{4}{*}{0,598} & $\begin{array}{l}\text { Knowledge of marketing } \\
\text { technologies (customer } \\
\text { orientation) }\left(\mathrm{BA}_{2}\right)\end{array}$ & 0,164 \\
\hline & & $\begin{array}{l}\text { Ability to adapt and act in a } \\
\text { new situation }\left(\mathrm{BA}_{3}\right)\end{array}$ & 0,168 \\
\hline & & $\begin{array}{l}\text { Knowledge of change } \\
\text { planning and development of } \\
\text { new projects }\left(\mathrm{BA}_{6}\right)\end{array}$ & 0,272 \\
\hline & & $\begin{array}{l}\text { Ability to evaluate and ensure } \\
\text { the quality of work performed } \\
\text { and decisions }\left(\mathrm{BA}_{8}\right)\end{array}$ & 0,172 \\
\hline \multirow{3}{*}{ 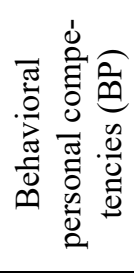 } & \multirow{3}{*}{0,259} & $\begin{array}{l}\text { Interaction risk management } \\
\text { skills }\left(\mathrm{BP}_{4}\right)\end{array}$ & 0,203 \\
\hline & & $\begin{array}{l}\text { Conflict management skills } \\
\left(\mathrm{BP}_{7}\right)\end{array}$ & 0,231 \\
\hline & & $\begin{array}{l}\text { The desire to succeed and } \\
\text { inspire the team }\left(\mathrm{BP}_{13}\right)\end{array}$ & 0,114 \\
\hline \multirow{4}{*}{ 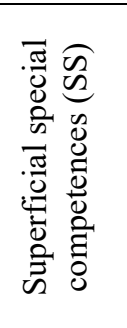 } & \multirow{4}{*}{0,099} & $\begin{array}{l}\text { Ability to plan and control } \\
\text { business processes }\left(\mathrm{SS}_{3}\right)\end{array}$ & 0,238 \\
\hline & & $\begin{array}{l}\text { Ability to work in an } \\
\text { international context }\left(\mathrm{SS}_{8}\right)\end{array}$ & 0,117 \\
\hline & & $\begin{array}{l}\text { Ability to motivate people } \\
\left(\mathrm{SS}_{10}\right)\end{array}$ & 0,163 \\
\hline & & $\begin{array}{l}\text { Knowledge of corporate } \\
\text { culture }\left(\mathrm{SS}_{11}\right)\end{array}$ & 0,167 \\
\hline \multirow{2}{*}{ 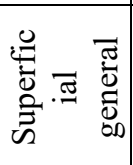 } & \multirow{2}{*}{0,044} & $\begin{array}{l}\text { Knowledge of analysis and } \\
\text { synthesis }\left(\mathrm{SG}_{2}\right)\end{array}$ & 0,185 \\
\hline & & $\begin{array}{l}\text { Reasonable decision making } \\
\text { skills }\left(\mathrm{SG}_{5}\right)\end{array}$ & 0,131 \\
\hline
\end{tabular}




\begin{tabular}{|l|l|l|}
\hline & $\begin{array}{l}\text { Ability to communicate in } \\
\text { state and foreign languages } \\
\left(\mathrm{SG}_{6}\right)\end{array}$ & 0,152 \\
\cline { 2 - 3 } & $\begin{array}{l}\text { Ability for continuous } \\
\text { learning and self-development } \\
\left(\mathrm{SG}_{8}\right)\end{array}$ & 0,257 \\
\hline
\end{tabular}

However, it is desirable to confirm the above key competencies with a certificate of at least one year of counseling experience. The results of the expert assessment on the third level of human capital development of the company "Improved set of competencies of a consultant in Ukraine, taking into account the International Standard ISO 20700:2017” Guidelines for management consulting services" in their importance are presented in Table 3 [21].

Table 3: The results of the assessment of competencies for III-level "An improved set of competencies for a consultant in Ukraine, taking into account the International Standard ISO 20700:2017"

\begin{tabular}{|c|c|c|c|}
\hline 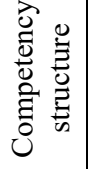 & Weight & General Competence (factors) & $\begin{array}{l}\text { Weight by } \\
\text { individual } \\
\text { factor }\end{array}$ \\
\hline \multirow{4}{*}{ 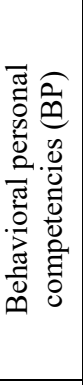 } & \multirow{4}{*}{0,658} & $\begin{array}{l}\text { Interaction risk management skills, } \\
\text { including. risk identification and ability } \\
\text { to assess it }\left(\mathrm{BP}_{5}\right)\end{array}$ & 0,185 \\
\hline & & Conflict management skills $\left(\mathrm{BP}_{6}\right)$ & 0,107 \\
\hline & & $\begin{array}{l}\text { Ability to adhere to ethical conduct and } \\
\text { the Code of Professional Conduct and } \\
\text { Ethics established at the national or } \\
\text { international level }\left(\mathrm{BP}_{11}\right)\end{array}$ & 0,182 \\
\hline & & $\begin{array}{l}\text { Ability to define success criteria to } \\
\text { ensure the required quality of results } \\
\left(\mathrm{BP}_{12}\right)\end{array}$ & 0,288 \\
\hline \multirow{6}{*}{ 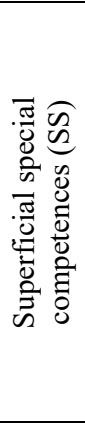 } & \multirow{6}{*}{0,215} & $\begin{array}{l}\text { Certificate confirming at least one year } \\
\text { of consulting management experience } \\
\left(\mathrm{SS}_{2}\right)\end{array}$ & 0,199 \\
\hline & & $\begin{array}{l}\text { Knowledge of marketing technologies } \\
\text { (customer orientation) }\left(\mathrm{SS}_{6}\right)\end{array}$ & 0,032 \\
\hline & & Ability to solve problem situations $\left(\mathrm{SS}_{7}\right)$ & 0,063 \\
\hline & & $\begin{array}{l}\text { Ability to form expert assessments and } \\
\text { conclusions }\left(\mathrm{SS}_{8}\right)\end{array}$ & 0,122 \\
\hline & & Knowledge of corporate culture (SS 12 ) & 0,187 \\
\hline & & $\begin{array}{l}\text { Ability to evaluate and ensure the } \\
\text { quality of work performed (projects) } \\
\left.\text { and decisions ( } \mathrm{SS}_{13}\right)\end{array}$ & 0,168 \\
\hline \multirow{6}{*}{ 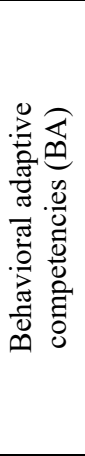 } & \multirow{6}{*}{0,096} & $\begin{array}{l}\text { Purposefulness in achieving results in } \\
\text { professional development }\left(\mathrm{BA}_{1}\right)\end{array}$ & 0,035 \\
\hline & & Ability to adapt to a new situation $\left(\mathrm{BA}_{2}\right)$ & 0,033 \\
\hline & & $\begin{array}{l}\text { Ability to successfully complete } \\
\text { customer tasks, ensuring goals, } \\
\text { deadlines and budgets are agreed and } \\
\text { delivered on time (BA5) }\end{array}$ & 0,266 \\
\hline & & $\begin{array}{l}\text { Knowledge of change planning and } \\
\text { development of new projects }\left(\mathrm{BA}_{6}\right)\end{array}$ & 0,286 \\
\hline & & $\begin{array}{l}\text { Creating innovative solutions for } \\
\text { customers }\left(\mathrm{BA}_{7}\right)\end{array}$ & 0,103 \\
\hline & & $\begin{array}{l}\text { Ability to effectively manage their own } \\
\text { time to complete tasks on time (BAs) }\end{array}$ & 0,049 \\
\hline \multirow{3}{*}{ 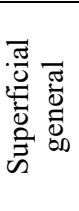 } & \multirow{3}{*}{0,031} & $\begin{array}{l}\text { Basic general knowledge (higher } \\
\text { education at I, II and III levels) }\left(\mathrm{SG}_{1}\right)\end{array}$ & 0,152 \\
\hline & & $\begin{array}{l}\text { Knowledge of analysis and synthesis } \\
\left(\mathrm{SG}_{2}\right)\end{array}$ & 0,05 \\
\hline & & $\begin{array}{l}\text { Applying knowledge and tools to create } \\
\text { value for the client }\left(\mathrm{SG}_{3}\right)\end{array}$ & 0,037 \\
\hline
\end{tabular}

\begin{tabular}{|l|l|l|}
\hline & $\begin{array}{l}\text { Skills in the use of presentation tools and } \\
\text { other research methods }\left(\mathrm{SG}_{4}\right)\end{array}$ & 0,371 \\
\cline { 2 - 3 } & $\begin{array}{l}\text { Ability to work with the regulatory } \\
\text { framework (SG6) }\end{array}$ & 0,071 \\
\cline { 2 - 3 } & $\begin{array}{l}\text { Ability to deepen knowledge and } \\
\text { improve skills based on experience of } \\
\text { own and other past project tasks }\left(\mathrm{SG}_{7}\right)\end{array}$ & 0,270 \\
\hline
\end{tabular}

The calculations carried out by a group of experts in the second stage to assess the set of competencies of the company's consultants by levels of development according to their importance allow ranking the competencies of human consulting company, which form the basis for building the package (Table 4) [20].

Table 4: Ranking of competencies by groups and levels of development human capital consulting company

\begin{tabular}{|c|c|c|c|c|c|c|}
\hline \multirow[t]{2}{*}{ 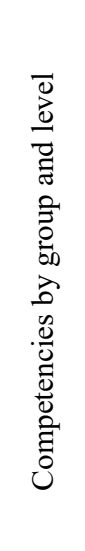 } & \multicolumn{2}{|c|}{ 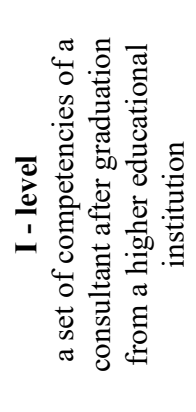 } & \multicolumn{2}{|c|}{ 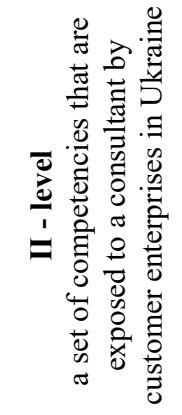 } & \multicolumn{2}{|c|}{ 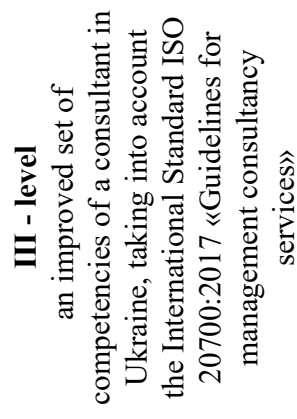 } \\
\hline & $\begin{array}{l}\frac{\vec{c}}{.00} \\
\frac{.00}{\vec{b}} \\
\overrightarrow{3}\end{array}$ & $\begin{array}{l}\text { 艺 } \\
\text { L }\end{array}$ & $\begin{array}{l}\frac{\vec{b}}{.00} \\
\frac{.00}{00} \\
\frac{0}{3}\end{array}$ & 节 & $\begin{array}{l}\overrightarrow{\overrightarrow{0}} \\
\frac{.00}{\overrightarrow{0}} \\
\overrightarrow{3}\end{array}$ & $\begin{array}{l}\text { 華 } \\
\text { ¿ }\end{array}$ \\
\hline 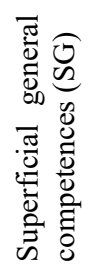 & 0,644 & 1 & 0,044 & 4 & 0,031 & 4 \\
\hline 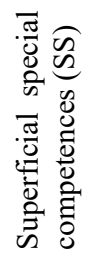 & 0,229 & 2 & 0,099 & 3 & 0,215 & 2 \\
\hline 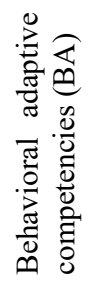 & 0,083 & 3 & 0,598 & 1 & 0,096 & 3 \\
\hline 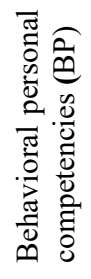 & 0,044 & 4 & 0,259 & 2 & 0,658 & 1 \\
\hline
\end{tabular}


Based on the results of the assessment of competencies, it was found that the competencies defined by employers, combined with theoretical and scientific knowledge, which are provided after completion of training at the university, form an employee of a consulting company, who has already become the company's human capital.

If we add to this level some competencies of the International Standard ISO 20700: 2017 «Guidelines for management consultancy services» according to the International Framework of Competence, developed under the leadership of the International Council of Management Consulting Institutions, we get an improved set of competencies for consultants of a consulting company.

According to the results of the competence assessment, high importance is given to "Behavioral personal competencies" $(0,658)$, which the consultant develops in the process of accumulation of professional skills and self-development on the basis of "Superficial special competencies" $(0,215)$ and "Superficial general competencies" $(0,031)$. In modern conditions, the Behavioral adaptive competencies group does not significantly influence the development of the company's consultants, modern gadgets and information platforms help them to adapt, etc.

Nevertheless, the main asset of the "Effective Consultant" model is the construction of the "Effective Consultant" intellectual resource package based on the results of the competence assessment for each individual group of consultants according to their key features (Table 5) [21].

The joint competencies of the consultants of the consulting company are as follows [20]:

- basic general knowledge (higher education for I-, II- and IIIlevels) (BP1);

- certificate confirming less than one year of experience in consulting management (SS2);

- knowledge of analysis and synthesis (SG2);

- application of knowledge and tools to create value for the client (SG3);

- ability to work with the regulatory framework (BP6);

- ability to deepen knowledge and improve skills based on the experience of one's own and other past tasks (SG7);

- knowledge of corporate culture (SS12).

The proposed model "Effective Consultant" regulates the process of forming a universal set of key competencies according to the levels of human capital development for a consultantmanager, consultant-expert and consultant-specialist in accordance with the demand by external or internal circumstances. The process of assessing competencies at structural levels has an innovative content that will certainly affect the quality of the company's consulting services. Under such conditions, the formation in the process of consulting interaction will ensure a balance between the performance and organizational efficiency of resources. Formed package of intellectual resource "effective consultant" is not universal. Over time, knowledge and information change, providing for a revision of the company's potential management system and its human capital management system. A decrease in the growth rate of labor productivity of employees of a consulting company at all levels of management will certainly affect the rate of profit growth. It is advisable to annually conduct expert research to revise the package of intellectual resource "Effective Consultant" and form such a set of key competencies, which is in demand by the time, existing and potential clients [20].

Table 5: A set of key competencies for the skin group and consultants at the border of the package "Intellectual resource"

\begin{tabular}{|c|c|}
\hline 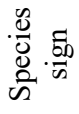 & Characteristics \\
\hline 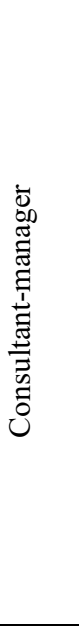 & $\begin{array}{l}\text { - ability to comply with ethical conduct and the Code of } \\
\text { Professional Conduct and Ethics established at the national } \\
\text { or international level }\left(\mathrm{BP}_{11}\right) \\
-\quad \text { ability to define success criteria to ensure the required } \\
\text { quality of results, and their application in professional } \\
\text { activities (BP } 12 \text { ) } \\
-\quad \text { knowledge of planning changes and developing new } \\
\text { projects (BA } 6 \text { ) } \\
-\quad \text { creation of innovative solutions for clients }\left(\mathrm{BA}_{7}\right) \\
-\quad \text { ability to assess and ensure the quality of work } \\
\left.\text { (projects) and solutions ( } \mathrm{SS}_{13}\right) \\
-\quad \text { skills of risk management, including risk identification } \\
\text { (prevention, mitigation, transmission, } \\
\text { contingencies) and the ability to assess it (BP } \mathrm{B}_{5} \text { ) } \\
-\quad \text { knowledge about the characteristics of the market for } \\
\text { consulting services, competitors and its opportunities } \\
\left(\mathrm{SS}_{4} \text { ). }\right.\end{array}$ \\
\hline 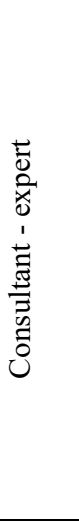 & $\begin{array}{l}\text { - ability to solve problem situations }\left(\mathrm{SS}_{7}\right) \text {; } \\
\text { - ability to form expert assessments and conclusions } \\
(\mathrm{SS} 8) \text {; } \\
\text { - ability to assess and ensure the quality of work } \\
\text { (projects) and solutions }\left(\mathrm{SS}_{13}\right) \text {; } \\
-\quad \text { ability to adapt to a new situation }\left(\mathrm{BA}_{2}\right) \text {; } \\
-\quad \text { conflict management skills }\left(\mathrm{BP}_{6}\right) \text {; } \\
-\quad \text { commitment to achieving professional development } \\
\text { results }\left(\mathrm{BA}_{1}\right) \text {; } \\
-\quad \text { ability to successfully solve client problems, ensuring } \\
\text { goals, timelines and budgets are agreed and delivered on } \\
\left.\text { time (BA } \mathrm{B}_{5}\right) \text {; } \\
-\quad \text { ability to effectively manage your own time to } \\
\text { complete tasks on time (BAs). }\end{array}$ \\
\hline 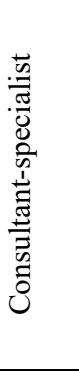 & $\begin{array}{l}\text { - commitment to achieving professional development } \\
\text { results }\left(\mathrm{BA}_{1}\right) \text {; } \\
-\quad \text { knowledge of marketing technologies (customer } \\
\text { focus) }\left(\mathrm{SS}_{6}\right) \text {; } \\
-\quad \text { ability to successfully solve client problems, ensuring } \\
\text { goals, timelines and budgets are agreed and delivered on } \\
\text { time (BA } \mathrm{B}_{5} \text {; } \\
-\quad \text { conflict management skills }\left(\mathrm{BP}_{6}\right) \text {; } \\
-\quad \text { ability to effectively manage your own time to } \\
\text { complete tasks on time (BA8). }\end{array}$ \\
\hline
\end{tabular}

To continuously improve their existing competencies and acquire new knowledge, consultants must distribute their stock, generate new knowledge, take courses to improve professional skills and engage in their own training during the implementation of consulting projects. Moreover, the knowledge transfer process, taking into account the key competencies of consultants, will take place in accordance with the consulting service standard created 
by the owners of the consulting company itself or proposed for use at the level of a regulatory and legislative act.

\section{Conclusions}

Based on the consideration of the above, we can conclude that the personnel management of the company today is expanding its economic content and acquires a new meaning as capital. The modern process of human capital management is aimed at its effective use and development. In these circumstances, the owner has the opportunity to maximize the return on the skills, knowledge of the worker, and the worker - to receive the maximum level of material and psychological satisfaction from his work. Then the goal of management acquires strategic development in two directions.

The first should provide for a high degree of competitiveness of the enterprise, flexibility of forms and methods of human capital management, intensification of labor of highly qualified workers and participation of workers in the distribution of profits. The second direction should include ensuring responsibility for the creation of competitive advantages of the enterprise by the employees themselves, and their participation in the affairs of the enterprise is achieved through such factors as effective organizational communication, high motivation and flexible leadership. However, in both the first and second directions, the role of human capital in the process of consulting interaction, accompanied by the value chain, is endless. The human capital of a consulting company is not just its main intellectual resource, its potential, in contrast to other resources, is formed through the renewal of intellectual knowledge and information. In these conditions, human capital becomes the source of the company's values, which over time are recognized as competitive advantages for a reasonable desire to transform resources into capital.

The article presents a scientific and methodological approach to building the model "Effective Consultant". The methodological basis for assessing competencies according to the "Effective Consultant" model has an innovative content. The proposed model regulates the process of forming a universal set of key competencies according to the levels of human capital development for a consultant-manager, consultant-expert and consultant-specialist. The Effective Consultant model takes into account a set of competencies in accordance with the demand from external or internal factors. In the course of the research, it was found that the weighty groups defined "Behavioral personal competencies» and "Superficial special competencies".

The "Effective Consultant" model has been tested and implemented in the activities of consulting companies in Ukraine, which allows to be recommended for widespread use by any consulting company in the world. Human resources and academic departments of the company can use the "Effective Consultant" profile of consultants as a tool for managing business processes. Consultants can use the recommendations as part of a scientific and methodological approach to building the model "Effective Consultant" as a source of personal growth. It is proposed to evaluate consultants periodically so that the dynamics of the development of their competencies can be tracked.

\section{References}

[1] V. Geitz, V. Seminozhenko, B. Kvasyuk, Strategic challenges of the XXI www.astesj.com century to society and economy, Phoenix, Kyiv, 2007.

[2] V. Muzychenko, Master class in personnel management, Gross Medi, Moscow, 2009.

[3] L. Spencer, S. Spencer, Competence at work, HIPPO, Moscow, 2005.

[4] C.K. Prahalad, G. Hamel, "The core competence of the corporation," Harvard Business Review, 68(3), 79-91, 1990, doi:10.1007/3-540-30763X_14.

[5] G. Hamel, C.K. Prahalad, Competing for the future. Creating the markets of tomorrow, Olymp-Busi, Moscow, 2002.

[6] J. Thompson, A. Strickland, Strategic management: concepts and situations for analysis, Williams, Moscow, 2006.

[7] Tuning Educational Structures in Europe, Mar. 2021.

[8] S. Shishov, I. Agapov, "Competence-based approach to education: a whim or a necessity?," Standards and Monitoring in Education, (2), 23-30, 2002.

[9] S. Bondar, "Competence of personality - an integrated component of student achievement," Biology and Chemistry School, (2), 8-9, 2003.

[10] Y. Frolov, D. Mathotin, "Competence model as a basis for assessing the quality of training," Higher Education Today, (8), 34-41, 2004.

[11] A. Khutorskoi, "Technology of designing key and subject competencies," Eidos, (4), 1, 2005.

[12] D. Sahal, Patterns of Technological Innovation, Addison-We, Massachusetts, 1981.

[13] O. Selivanonova, Modern linguistics, Environmen, Poltava, 2006.

[14] P. Drucker, The Essential Drucker: In One Volume the Best of Sixty Years of Peter Drucker's Essential Writings on Management, 2015.

[15] T.H. Davenport, Process Innovation: Reengineering Work through Information Technology, Harvard Bu, Boston, 1992.

[16] Plato, Complete Works - Philosophy, Cambridge, 1997.

[17] I. Nonaka, H. Takeuchi, The Knowledge-Creating Company: How Japanese Companies Create the Dynamics of Innovation, Oxford Uni, New York, 1995.

[18] N. Kuzminska, Forecasting of innovative development of the enterprises of oilseed industry, Київ.

[19] T. Shultz, Human Capital in the International Encyclopedia of the Social Sciences, New York, 1968.

[20] G. Becker, Human Capital, Columbia U, New York, 1964.

[21] N. Yevtushenko, Organizational and economic mechanism of consulting interaction of enterprises of Ukraine, Kyiv, 2019.

[22] N. Yevtushenko, The mechanism of consulting interaction of enterprises in the market of telecommunication services of Ukraine, SIC GROUP, Kyiv, 2017.

[23] N. Yevtushenko, "Methodological principles for establishment of consulting cooperation organizational and economic mechanism," Economic Processes Management: International Scientific E-Journal, (2), 2017.

[24] V. Zakharchenko, V. Lugovyi, Y. Rashkevich, Y. Talanova, Development of educational programs. Guidelines, Priorities, Kyiv, 2014. 